\title{
Correction to: Utility of the New Indian Society of Paediatric and Adolescent Endocrinology (ISPAE) Guidelines for Congenital Hypothyroidism Screening in a High Risk Unit
}

\author{
Lakshmi Venugopalan ${ }^{1} \cdot$ Sugapriya Paranjyothi ${ }^{2}$. Anupama Sankaran² $\cdot$ Hemchand Krishna Prasad $^{3}$. \\ Gnanabalan Murugesan ${ }^{1} \cdot$ R. Shanmughasundaram ${ }^{1}$
}

Published online: 17 September 2021

@ ) Dr. K C Chaudhuri Foundation 2021

\section{Correction to: The Indian Journal of Pediatrics https://doi.org/10.1007/s12098-020-03555-x}

The statement: "Out of the 83 cases, 36 (43.3\%), 26 (31.3\%) and $21(25.3 \%)$ cases had screening TSH $>20 \mu \mathrm{IU} / \mathrm{mL}, 6-20$ $\mu \mathrm{IU} / \mathrm{mL}$ and $<6 \mu \mathrm{IU} / \mathrm{mL}$, respectively" should read as the follows:

"Out of the 83 cases, 36 (43.3\%), $16(19.2 \%)$ and 31 (37.3\%) cases had screening TSH $>20 \mu \mathrm{IU} / \mathrm{mL}, 6-20 \mu \mathrm{IU} /$ $\mathrm{mL}$ and $<6 \mu \mathrm{IU} / \mathrm{mL}$, respectively".
This appears in the abstract (results 3rd line), results section 3rd paragraph, and discussion section 2nd paragraph.

However, the authors wish to state that this does not alter the results of the study, inference and final conclusion.

The original article has been corrected.

Publisher's Note Springer Nature remains neutral with regard to jurisdictional claims in published maps and institutional affiliations.

The original article can be found online at https://doi.org/10.1007/ s12098-020-03555-x.

Hemchand Krishna Prasad pediatricendocrinology.mehta@gmail.com

1 Department of Neonatology, Mehta Multispeciality Hospitals India Pvt Ltd, Chennai, India

2 Department of Pediatrics, Mehta Multispeciality Hospitals India Pvt Ltd, Chennai, India

3 Department of Pediatric Endocrinology and Diabetes, Mehta Multispeciality Hospitals India Pvt Ltd, Chennai, India 